\title{
Shell disease does not affect biochemical profiles of the North Sea brown shrimp Crangon crangon
}

\author{
Alexandra Segelken-Voigt ${ }^{1,6, *}$, Wilhelm Hagen ${ }^{2}$, Gabriele Gerlach $^{1,3,4}$, \\ Julia Strahl ${ }^{1,3,5}$ \\ ${ }^{1}$ Institute of Biology and Environmental Sciences, Carl von Ossietzky University Oldenburg, Carl von Ossietzky Str. 9-11, \\ 26111 Oldenburg, Germany \\ ${ }^{2}$ BreMarE - Bremen Marine Ecology, Marine Zoology, University of Bremen, PO Box 330440, 28334 Bremen, Germany \\ ${ }^{3}$ Helmholtz-Institute for Functional Marine Biodiversity at the University of Oldenburg (HIFMB), \\ Ammerländer Heerstrasse 231, 26129 Oldenburg, Germany \\ ${ }^{4}$ Centre of Excellence for Coral Reef Studies and School of Marine and Tropical Biology, James Cook University, \\ 4811 Queensland, Australia
}

${ }^{5}$ Alfred Wegener Institute Helmholtz Centre for Polar and Marine Research, Am Handelshafen 12, 27570 Bremerhaven, Germany

${ }^{6}$ Present address: Institute of Fisheries, State Research Center of Agriculture and Fisheries Mecklenburg-Vorpommern, 18375 Born, Germany

\begin{abstract}
The brown shrimp Crangon crangon is a key component of the North Atlantic coastal food web and an important target species for the fishery economy. As the brown shrimp contains large amounts of protein and essential fatty acids, its consumption makes it a beneficial choice for humans. Commercially harvested crustaceans like C. crangon are frequently affected by bacterial shell disease, with necrotizing erosions and ulcerations of the cuticle. To determine whether shell disease influences the nutritional value of C. crangon, total protein and lipid contents, as well as fatty acid compositions of muscle tissue and hepatopancreas, together with the hepatosomatic index, were examined in healthy and affected individuals. The biochemical composition of the tissues did not differ significantly between the 2 groups. Also, the hepatosomatic index, as an indicator of energy reserves in shrimps, was similar between healthy and affected animals. Our results indicate that the nutritional value of C. crangon is not affected by shell disease, as long as it remains superficial as in the present study.
\end{abstract}

KEY WORDS: Black spot disease $\cdot$ Lipids $\cdot$ Fatty acids $\cdot$ Omega- $3 \cdot$ EPA $\cdot$ DHA $\cdot$ Hepatosomatic index

Resale or republication not permitted without written consent of the publisher

\section{INTRODUCTION}

The brown shrimp Crangon crangon (Linnaeus, 1758 ) is one of the most ecologically and economically important invertebrate species along the North Atlantic coast of Europe. It forms a key component in the marine food web and is commercially harvested throughout most of its distribution range, with a yield of more than $35000 \mathrm{t} \mathrm{yr}^{-1}$ (Revill \& Holst 2004, Beukema \& Dekker 2005, ICES 2015). Several exploited crustaceans, such as the brown shrimp, the edible crab Cancer pagurus, or the American lobster Homarus americanus, can be affected by shell disease (Smolowitz et al. 2005, Shields 2013), with significant commercial implications. For example, for the US fishing industries, shell disease in the American lobster has caused economic losses reaching millions of dollars, since it directly renders affected individuals unmarketable as a live product and indirectly affects reproduction and recruitment (Ayres \& Edwards 1982, Getchell 1991, Wahle et al. 2009, Lafferty et al. 2015). 
The term 'shell disease' includes both enzootic and epizootic shell disease and describes different forms of necrotic lesions and disintegrations of the cuticle of crustaceans resulting from distinct etiologies and causative agents (Dyrynda 1998, Vogan \& Rowley 2002, Shields 2013). Enzootic or classical shell disease induces irregularly shaped lesions of the cuticle that are commonly observed in lobsters, crabs, and shrimps (Smolowitz et al. 1992, Vogan et al. 1999). In contrast, the more aggressive epizootic shell disease progresses inwards through the carapace and occurs mainly in the American lobster (Castro \& Angell 2000, Chistoserdov et al. 2005, Smolowitz et al. 2005). In both disease forms, the characteristic black ulcerations may be caused by a pathogenic shift in the bacterial shell community. In this context, a multitude of different chitinolytic and lipolytic bacteria strains have been observed, including species in genera such as Aquimarina, Pseudomonas, and Vibrio (Rosen 1967, Meres et al. 2012, Feinman et al. 2017).

Some of these chitinolytic and lipolytic bacteria are also present on the cuticle of healthy crustaceans (Meres et al. 2012, Kraemer et al. 2020). Before the symbiosis becomes pathogenic, and chitin degradation by bacteria can occur, a portal of entry is required in the form of destruction of the outermost non-chitinous epicuticle by mechanical (Vogan et al. 1999) or chemical abrasion (Schlotfeldt 1972), or predatory or cannibalistic attacks (Dyrynda 1998). In addition, toxins, pollution, and higher temperatures may further accelerate bacterial growth and reduce the resistance of the host (Young \& Pearce 1975, Glenn \& Pugh 2006, Laufer et al. 2012).

Superficial early stages of shell disease are usually not fatal, and the affected individual may overcome the condition by molting (Smolowitz et al. 1992, Barris et al. 2018, Segelken-Voigt et al. 2018). Nevertheless, shell disease can also cause death, either directly through invading pathogens into the underlying soft tissues, leading to internal infections, or indirectly, through impaired feeding function or locomotion, due to lesions on the appendages (Smolowitz et al. 1992, Vogan et al. 2001). Additionally, shell disease can interfere with immunocompetence (Chen et al. 1995, Tlusty et al. 2007) and thus reduce the survival chance of affected crustaceans (Smolowitz et al. 2005, Hoenig et al. 2017, Segelken-Voigt et al. 2018). Likewise, affected crustaceans may be energetically compromised or produce elevated levels of ecdysone due to altered gene expressions and hormone levels, resulting in changes in the molting behavior and cellular stress response (Laufer et al. 2005, Castro et al. 2006, Tarrant et al. 2012).

In marine invertebrates, proteins and lipids play an important role as the main energy reserves or as cell membrane components (Kattner et al. 1994, García et al. 2002, Lee et al. 2006, Jimeńez \& Kinsey 2015). During stressful environmental conditions (e.g. food scarcity, heavy metal or pathogen exposure), energy reserves can be mobilized to maintain physiological functions and increase the resilience of an organism (Floreto et al. 2000, Verslycke et al. 2003, Sacristán et al. 2017). In decapods, lipids are primarily stored in the hepatopancreas (midgut gland), which synthesizes enzymes and lipids (Chang \& O'Connor 1983, Diaz et al. 2010, Martínez-Alarcón et al. 2019). Physiological impairments and diseases directly affect this organ (Johnson 1980), and a low hepatosomatic index (HSI) could indicate poor health or reduced food intake. For example, $H$. americanus affected by shell disease have significantly lower lipid levels, including omega-3 fatty acids, in their hepatopancreas compared to healthy specimens, as well as a lower HSI, indicating a reduced lipid-storage capacity (Floreto et al. 2000).

Our study organism, C. crangon, contributes important nutritional components to the human diet. It contains high amounts of essential omega-3 fatty acids such as eicosapentaenoic acid (EPA, 20:5(n-3)) and docosahexaenoic acid (DHA, 22:6(n-3)), which can improve human health status and reduce the risk of cancer, cardiovascular diseases, and diabetes (Heu et al. 2003, Harper \& Jacobson 2005, Vaughan et al. 2013, Calder 2017). The biochemical composition (e.g. contents of proteins and lipids) of shrimp and other edible crustaceans may reflect their physiological state of health and, thus, their nutritional value for human consumption. To investigate a possible relationship between shell disease and the nutritional value of C. crangon, total protein and lipid contents and the fatty acid composition were analyzed in 2 tissue types of healthy and affected brown shrimp. The hepatopancreas served as an indicator of the metabolic state of the shrimp, whereas muscle tissue reflected the nutritional value of the animal.

\section{MATERIALS AND METHODS}

\subsection{Sampling and preparation of Crangon crangon}

In July 2017, C. crangon specimens were collected at depths of 8-10 $\mathrm{m}$ by a beam trawl of RV 'Uthörn' in 
the Weser estuary in the German Bight, North Sea $\left(53^{\circ} 38.90^{\prime} \mathrm{N}, 8^{\circ} 25.19^{\prime} \mathrm{E}\right)$ (Fig. 1). After sampling, the shrimp were immediately weighed (fresh mass) and measured (total length from end of the rostrum to end of the tail). In total, 41 adult males and non-egg-bearing females were analyzed for signs of shell disease (see Fig. 2). The affected individuals were photographed with a Nikon P7000, and the size of the black ulcerations on the shell was measured using ImageJ software (http://rsb.info.nih.gov/ij/) (Table 1). To calculate the relative size of black ulcerations in percentage coverage, the size of the necrotic lesions was normalized to the body length of the individual. In total, 18 healthy ( $0 \%$ shell-disease coverage) and 23 affected shrimp ( $>5 \%$ shell-disease coverage) were used for subsequent biochemical analyses. The individuals were snap-frozen in liquid nitrogen after measurement and dissected at a later stage for tissue sampling. The hepatopancreas and a piece of the muscle from the second abdominal segment were stored at $-80^{\circ} \mathrm{C}$ until further biochemical analyses. As an indicator of the energetic status of the shrimp, the hepatopancreas was weighed to determine the HSI ( $\%$ of fresh mass). This value was computed as HSI $\%=\mathrm{HW} / \mathrm{BW} \times 100$, where HW is the wet mass of the hepatopancreas (mg), and BW is the wet mass of the brown shrimp (mg). All animal work was conducted according to the German animal protection law (approval no. 33.19-42502-05-15A542).

\subsection{Total protein content}

The total protein content was determined following the protocol of Lowry et al. (1951) and using the DC $^{\mathrm{TM}}$ Protein Assay Kit (BIO RAD Laboratories) with bovine serum albumin (BSA) standard. The standard curve consisted of 5 dilution standards of known protein concentration $\left(0,0.19,0.38,0.76,1.52 \mathrm{mg} \mathrm{ml}^{-1}\right)$ mixed in $1 \mathrm{M} \mathrm{NaOH}$ (sodium hydroxide). Tissue samples of muscle and hepatopancreas were diluted 1:200 (m:v) in $1 \mathrm{M} \mathrm{NaOH}$. Small glass beads $\varnothing$ $0.1 \mathrm{~mm}$ ) were added to the samples. Standards and samples were homogenized by vortexing (Vortex Genie 2, Scientific Industry) for $30 \mathrm{~s}$ and incubated on a rotating heating block (Thermomixer comfort, Eppendorf) for $20 \mathrm{~min}$ at $50^{\circ} \mathrm{C}$ and $200 \times g$. These steps were repeated 3 times. Samples were centrifuged for $10 \mathrm{~min}$ at room temperature and $1500 \times \mathrm{g}$. Aliquots of $5 \mu \mathrm{l}$ of the supernatants and the protein standards, respectively, were transferred (in duplicate) into individual wells of a 96-well microtiter plate. Aliquots of $25 \mu \mathrm{l}$ alkaline copper tartrate solution (Bio-

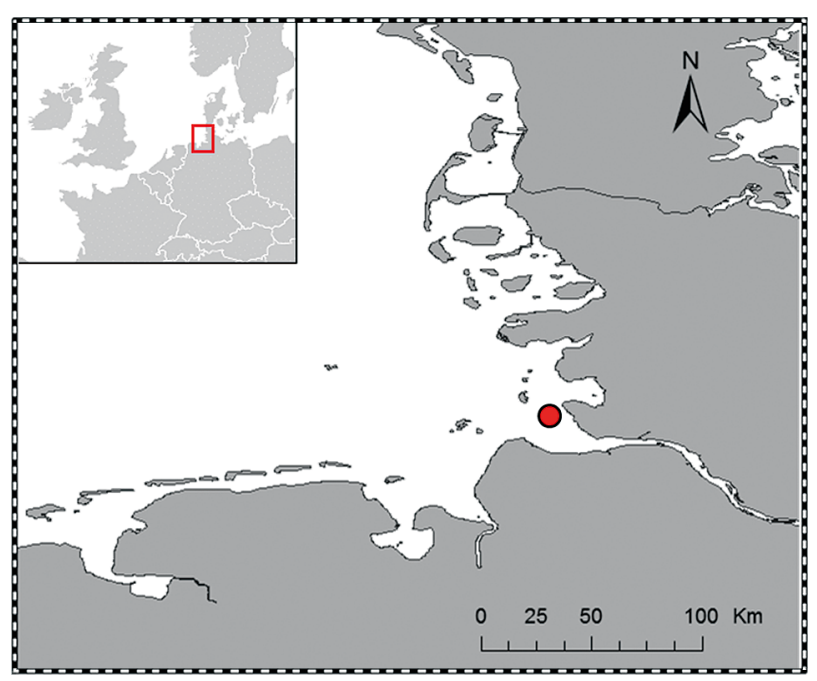

Fig. 1. Sampling location of brown shrimp Crangon crangon in the Weser estuary in the German Bight, North Sea $\left(53^{\circ} 38.90^{\prime} \mathrm{N}, 8^{\circ} 25.19^{\prime} \mathrm{E}\right)$

Rad DC Reagent A) and $200 \mu \mathrm{l}$ Folin reagent (BioRad DC Reagent B) were added to each sample and standard. After 15 min of incubation in the dark, the samples were measured spectrophotometrically in a microplate reader (Infinite 200 Pro, Tecan) at a wavelength of $750 \mathrm{~nm}$. Total protein content was calculated based on the standard curve and expressed in $\%$ of dry mass (\% DM).

\subsection{Total lipid content}

The total lipid content was determined following the methods of Folch et al. (1957) and Hagen et al. (2000). Muscle and hepatopancreas samples were lyophilized for $48 \mathrm{~h}$ and transferred to an evacuated desiccator for $30 \mathrm{~min}$. The pulverized tissue samples were weighed and homogenized with Potter homogenization and ultrasonic disruption, and then total lipids were extracted with dichloromethane/ methanol (DCM/MeOH, 2:1 per volume). This procedure was repeated, and each time the supernatant was transferred into a clean test tube. After adding $2 \mathrm{ml} \mathrm{KCl}$ (potassium chloride) solution $(0.88 \%)$, the samples were centrifuged at $1495 \times g\left(10 \mathrm{~min}\right.$ at $\left.2^{\circ} \mathrm{C}\right)$. After phase separation, the lipid phase was pipetted into a clean glass vial and the solvents evaporated under a stream of nitrogen. The pure, extracted lipids were weighed and the total lipid contents of muscle and of hepatopancreas were calculated in \% DM. For subsequent fatty acid analyses, the extracted lipids were redissolved in $\mathrm{DCM} / \mathrm{MeOH}$ and stored in nitrogen at $-80^{\circ} \mathrm{C}$. 
Table 1. List of Crangon crangon specimens sampled for biochemical analyses with total length, fresh masses of the individual and the hepatopancreas (HP), sex (F: female; M: male), and shell-disease coverage

\begin{tabular}{|c|c|c|c|c|c|}
\hline $\begin{array}{l}\text { Sample } \\
\text { no. }\end{array}$ & $\begin{array}{c}\text { Total } \\
\text { length }(\mathrm{mm})\end{array}$ & $\begin{array}{c}\text { Fresh } \\
\text { mass (mg) }\end{array}$ & $\begin{array}{c}\mathrm{HP} \\
\text { mass (mg) }\end{array}$ & Sex & $\begin{array}{l}\text { Shell-disease } \\
\text { cover }\left(\mathrm{mm}^{2}\right)\end{array}$ \\
\hline 1 & 59 & 1530 & 50 & F & 0 \\
\hline 2 & 55 & 1390 & 69 & F & 0 \\
\hline 3 & 50 & 1000 & 57 & F & 0 \\
\hline 4 & 52 & 1240 & 66 & M & 0 \\
\hline 5 & 55 & 1150 & 61 & $\mathrm{~F}$ & 0 \\
\hline 6 & 50 & 890 & 46 & $\mathrm{~F}$ & 0 \\
\hline 7 & 53 & 1270 & 62 & $\mathrm{M}$ & 0 \\
\hline 8 & 56 & 1680 & 63 & $\mathrm{~F}$ & 0 \\
\hline 9 & 55 & 1420 & 53 & $\mathrm{~F}$ & 0 \\
\hline 10 & 51 & 1230 & 78 & $\mathrm{~F}$ & 0 \\
\hline 11 & 47 & 890 & 49 & $\mathrm{~F}$ & 0 \\
\hline 12 & 47 & 730 & 47 & M & 0 \\
\hline 13 & 55 & 1130 & 70 & $\mathrm{~F}$ & 0 \\
\hline 14 & 55 & 1500 & 60 & $\mathrm{~F}$ & 0 \\
\hline 15 & 53 & 1370 & 93 & $\mathrm{~F}$ & 0 \\
\hline 16 & 52 & 1300 & 59 & $\mathrm{~F}$ & 0 \\
\hline 17 & 50 & 1030 & 42 & M & 0 \\
\hline 18 & 58 & 1930 & 90 & $\mathrm{~F}$ & 0 \\
\hline 19 & 50 & 1240 & 57 & $\mathrm{~F}$ & 3.2 \\
\hline 20 & 56 & 1760 & 61 & $\mathrm{~F}$ & 3.3 \\
\hline 21 & 60 & 1900 & 79 & $\mathrm{~F}$ & 3.4 \\
\hline 22 & 55 & 1360 & 77 & $\mathrm{~F}$ & 3.4 \\
\hline 23 & 54 & 1400 & 78 & $\mathrm{~F}$ & 3.6 \\
\hline 24 & 56 & 1650 & 96 & $\mathrm{~F}$ & 3.8 \\
\hline 25 & 51 & 1130 & 77 & M & 4.3 \\
\hline 26 & 56 & 1540 & 76 & $\mathrm{~F}$ & 4.4 \\
\hline 27 & 53 & 2080 & 79 & $\mathrm{~F}$ & 4.4 \\
\hline 28 & 41 & 430 & 29 & M & 4.6 \\
\hline 29 & 51 & 1010 & 64 & $\mathrm{~F}$ & 4.8 \\
\hline 30 & 50 & 1130 & 54 & $\mathrm{~F}$ & 5.1 \\
\hline 31 & 46 & 920 & 30 & M & 5.2 \\
\hline 32 & 56 & 1530 & 77 & $\mathrm{~F}$ & 5.3 \\
\hline 33 & 50 & 1030 & 41 & $\mathrm{~F}$ & 5.6 \\
\hline 34 & 49 & 1030 & 59 & $\mathrm{~F}$ & 5.6 \\
\hline 35 & 54 & 1320 & 60 & $\mathrm{~F}$ & 5.8 \\
\hline 36 & 55 & 1540 & 96 & $\mathrm{~F}$ & 5.9 \\
\hline 37 & 50 & 990 & 48 & M & 6.8 \\
\hline 38 & 54 & 1270 & 51 & $\mathrm{~F}$ & 7.6 \\
\hline 39 & 44 & 610 & 42 & M & 8.2 \\
\hline 40 & 53 & 1070 & 46 & $\mathrm{~F}$ & 8.9 \\
\hline 41 & 55 & 1500 & 69 & $\mathrm{~F}$ & 9.8 \\
\hline
\end{tabular}

\subsection{Fatty acid composition}

A subsample of the redissolved lipid samples was hydrolyzed to convert the fatty acids to methylester derivatives (FAMEs). This trans-esterification was performed by heating the samples with $3 \% \mathrm{H}_{2} \mathrm{SO}_{4}$ (sulfuric acid) in methanol and $250 \mu \mathrm{l}$ hexane for $4 \mathrm{~h}$ at $80^{\circ} \mathrm{C}$ (Kattner \& Fricke 1986). FAMEs were dissolved in $1 \mathrm{ml}$ hexane and their composition analyzed in a gas chromatograph (HP 6890; Agilent Technologies) equipped with a DB-FFAP column (30 $\mathrm{m}$ length, $0.25 \mathrm{~mm}$ inner diameter, $0.25 \mu \mathrm{m}$ film thickness) operating with an automated temperature vaporizer injector and with helium as carrier gas. Fatty acid peaks were identified by comparing their retention times with 2 standards of known composition (copepod lipids and menhaden fish oil). The quantities of the individual fatty acids were expressed as mass percentage of total fatty acids ( $\%$ TFA).

\subsection{Statistical analysis}

Before running the statistical tests in SPSS 24, the data were checked for normality and homogeneity of variances. Initially, we separated the shrimp into 3 groups to examine potential differences between healthy ( $0 \%$ shell-disease coverage), moderately $(5-10 \%$ shell-disease coverage, Fig. 2A,B), and severely affected shrimp ( $>10 \%$ shell-disease coverage, Fig. 2C-F).

The biochemical profiles (total lipid and protein levels plus fatty acid compositions) in these 3 groups, as well as separately in females and males, were then visualized by non-metric multidimensional scaling (nMDS) based on Bray-Curtis similarity, after a squareroot-transformation of the data (Kruskal \& Wish 1978) using PRIMER 6.1.6 (Clarke \& Gorley 2006). Additionally, a permutational multivariate analysis of variance (PERMANOVA, Anderson 2001) was performed to test for differences in biochemical composition (total amount of lipids and proteins as well as fatty acid composition) of muscle tissue and hepatopancreas with the factors 'shelldisease coverage' (fixed at 3 levels = healthy, moderately, and severely affected) and 'sex' (fixed at 2 levels = female and male) based on the Bray-Curtis similarity matrix of square-root-transformed data. The analysis was run using the permutation of residuals under a reduced model, with 9999 permutations and type III sums of squares.

As no differences were observed between moderately and severely affected shrimp, we pooled these individuals into 1 group (see also Fig. 2). To test for significant differences in the biochemical parameters 

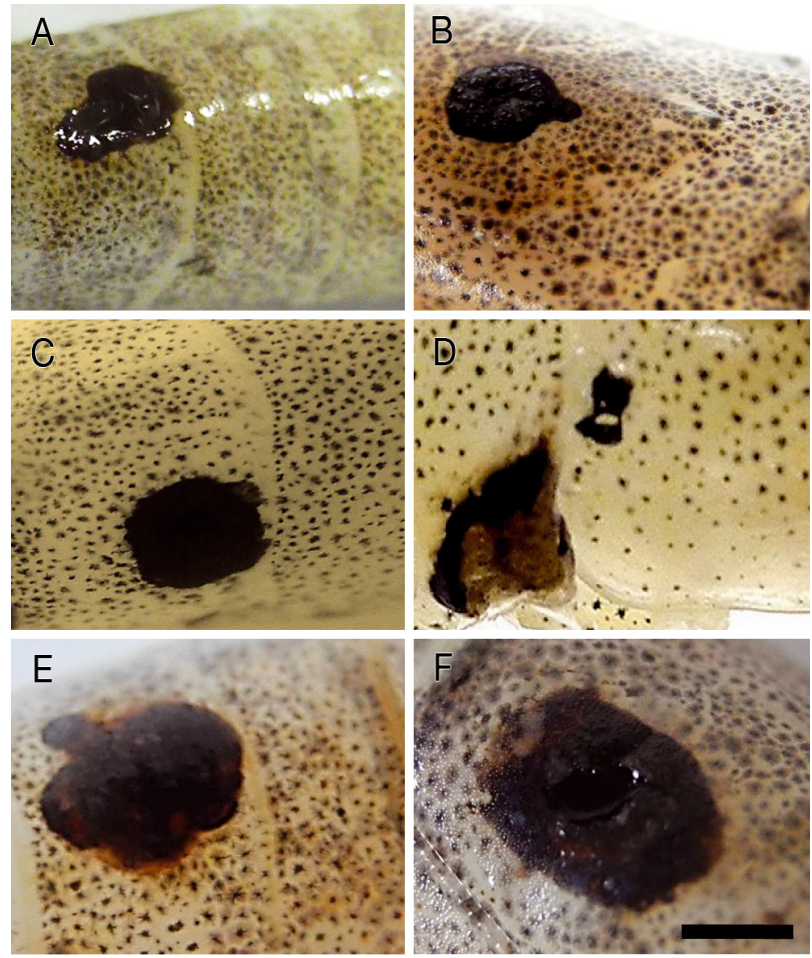

Fig. 2. Shell disease in Crangon crangon with varying lesion sizes: (A) 3.6, (B) 4.8, (C) 5.8, (D) 6.8, (E) 8.9, (F) $9.8 \mathrm{~mm}^{2}$. Scale bar $=2.5 \mathrm{~mm}$

and the HSI between healthy and shell-disease affected animals, a $t$-test or a 1-way ANOVA was applied (depending on the number of groups). The significance level was set to $\alpha=0.05$.

\section{RESULTS}

There were no apparent differences in the biochemical profiles of the hepatopancreas and muscle of healthy vs. affected shrimp. The nMDS plot (Fig. 3) displaying the composition of fatty acids as well as the amounts of lipids and proteins in the muscle (Fig. 3A) and in hepatopancreas (Fig. 3B) revealed no clustering for healthy, moderately, and severely affected brown shrimp. In the muscle tissue and hepatopancreas (Table 2), the PERMANOVA showed neither specific differences between the 3 groups, nor between sexes. In the following, all individuals were therefore classified as either healthy or shell-disease affected.

Fresh mass, total length, and HSI did not differ significantly between healthy and shell-disease affected brown shrimp. Mean \pm SD fresh mass and total length of Crangon crangon amounted to $1260 \pm$ $300 \mathrm{mg}$ and $53 \pm 4 \mathrm{~mm}$ in healthy individuals and

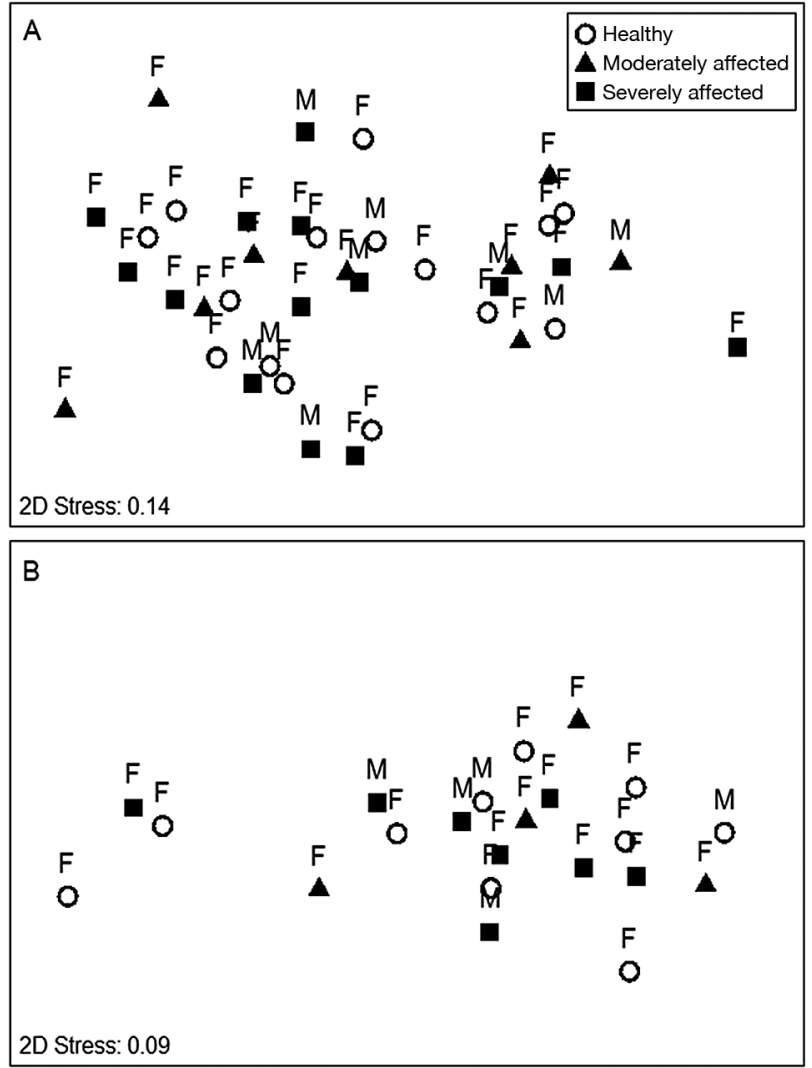

Fig. 3. Non-metric multidimensional scale ordination of Bray-Curtis similarity from square-root transformed data of biochemical compositions of (A) muscle and (B) hepatopancreas of Crangon crangon between the 3 health categories. Open circles represent healthy shrimp, black squares represent severely affected shrimp, and black triangles represent moderately affected shrimp. Individuals are further differentiated by sex (F: female; M: male)

Table 2. Results of PERMANOVA testing for differences in biochemical composition of muscle and hepatopancreas of Crangon crangon between the 3 health categories (healthy, moderate, and severely shell-disease affected), and between the 2 sexes (female and male); p (perm) refers to the significance level assessed by a permutation test

\begin{tabular}{|lccc|}
\hline Source & df & Pseudo- $F$ & $\mathrm{p}$ (perm) \\
\hline Muscle & & & \\
Shell disease & 2 & 0.8268 & 0.577 \\
Sex & 1 & 1.9516 & 0.102 \\
Shell disease $\times$ sex & 2 & 0.7159 & 0.701 \\
Residuals & 32 & & \\
Total & 37 & & \\
Hepatopancreas & & & \\
Shell disease & 2 & 0.4912 & 0.7849 \\
Sex & 1 & 0.6097 & 0.5567 \\
Shell disease $\times$ sex & 1 & 0.9694 & 0.3369 \\
Residuals & 17 & & \\
Total & 21 & & \\
\hline
\end{tabular}


$1280 \pm 400 \mathrm{mg}$ and $52 \pm 5 \mathrm{~mm}$ in the affected animals. The mean hepatopancreas mass was $61 \pm 18 \mathrm{mg}$ in healthy and $62 \pm 22 \mathrm{mg}$ in affected shrimp. This resulted in an HSI of $5.0 \pm 1.0 \%$ in healthy and $4.9 \pm$ $1.0 \%$ in affected shrimp $(t=-0.060, \mathrm{p}=0.953)$.

Mean total protein and lipid contents in muscle and in hepatopancreas tissue did not differ significantly between healthy and affected $C$. crangon. The total protein content in the muscle accounted for $65.9 \pm$ $6.8 \% \mathrm{DM}$ in the healthy and $65.3 \pm 9.7 \% \mathrm{DM}$ in the affected brown shrimp $(t=-0.245, \mathrm{p}=0.808$, Fig. 4A). In the hepatopancreas, the total protein content averaged $52.6 \pm 11.3 \%$ DM in the healthy and $53.4 \pm 7.1 \%$ DM in the affected shrimp $(t=0.188$, $\mathrm{p}=0.853$, Fig. 4B). The total lipid content of the muscle was $6.3 \pm 0.9 \% \mathrm{DM}$ in healthy and $5.8 \pm 1.0 \% \mathrm{DM}$ in affected $C$. crangon ( $t=-1.486, p=0.146$, Fig. $4 \mathrm{C})$. The hepatopancreas had a mean total lipid content of
$20.9 \pm 6.1 \% \mathrm{DM}$ in healthy animals, and $20.5 \pm 5.2 \%$ DM in affected shrimp $(t=-0.158, \mathrm{p}=0.876$, Fig. 4D).

In total, 16 fatty acids were identified, each exceeding $1 \%$ of TFAs (Table 3). Major fatty acids in both tissue types of healthy and affected animals were palmitic acid (16:0), oleic acid (18:1(n-9)), eicosapentaenoic acid (EPA, 20:5(n-3)), and docosahexaenoic acid (DHA, 22:6(n-3)). Fatty acid compositions of the muscle and of the hepatopancreas did not differ significantly between the 2 C. crangon groups. In the muscle, all omega-3 fatty acids ( $\Sigma n-3)$ accounted for $46.2 \pm 1.7 \%$ of TFAs in the healthy and $46.1 \pm 2.6 \%$ of TFAs in the affected shrimp $(t=0.108$, $\mathrm{p}=0.914)$. The omega-3 fatty acids in the hepatopancreas amounted to $43.1 \pm 5.8 \%$ in healthy and $43.5 \pm$ $4.5 \%$ in affected individuals $(t=-0.188, \mathrm{p}=0.853)$.

The compositions of saturated (SFAs), monounsaturated (MUFAs), and polyunsaturated fatty acids

\section{Muscle}
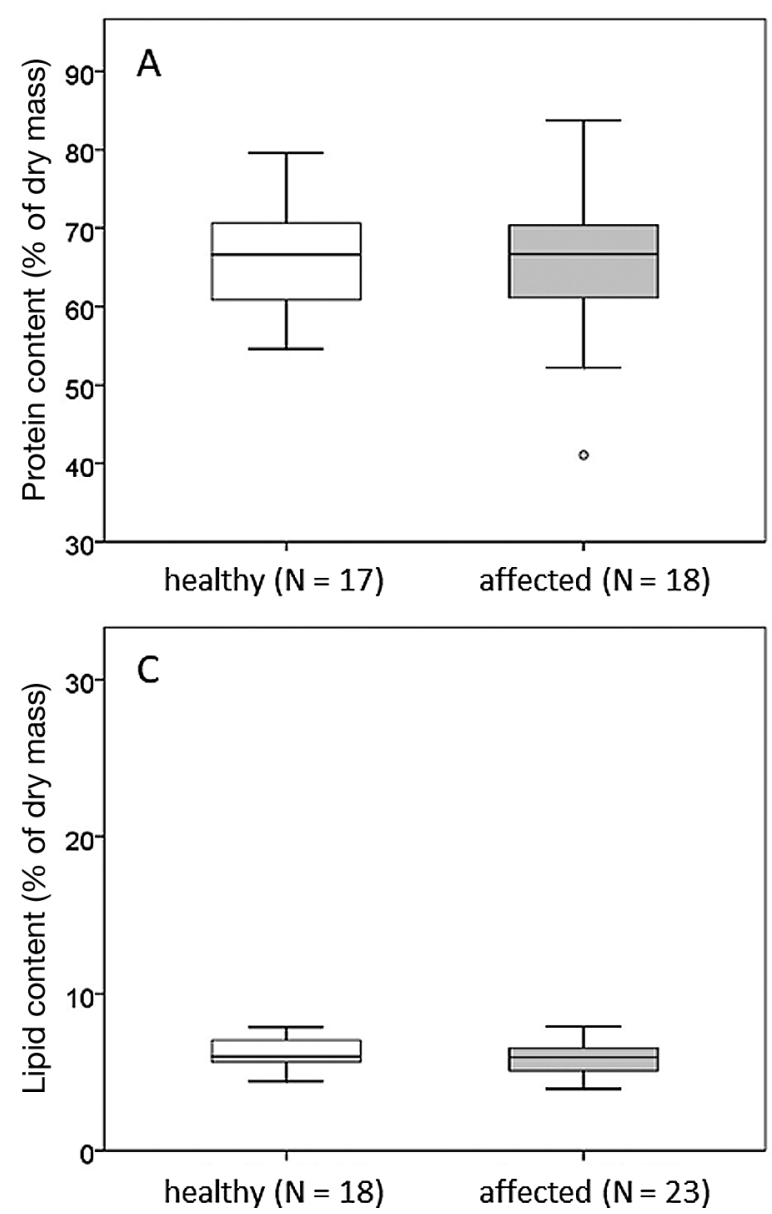

Hepatopancreas
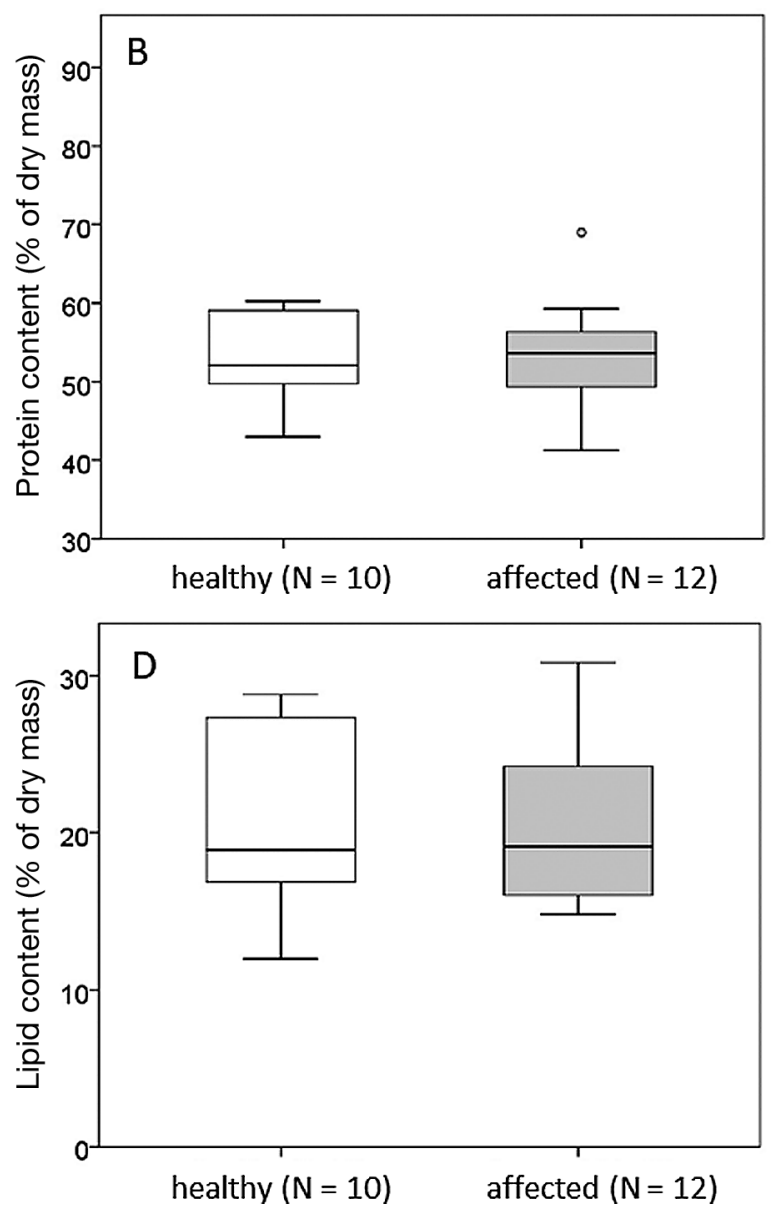

Fig. 4. Total protein contents in (A) muscle tissue and (B) hepatopancreas, and total lipid contents in (C) muscle and (D) hepatopancreas of healthy and shell-disease affected Crangon crangon. The center line in the box plot represents the median with upper and lower quartiles, whiskers indicate minima and maxima, and open circles are outliers 
Table 3. Fatty acid (FA) compositions (mass \% of total FAs greater than $1 \%$ ) of muscle tissue and of hepatopancreas of healthy and shell-disease affected Crangon crangon. Values represent means \pm SD. SFA: saturated FA; MUFA: monounsaturated FA; PUFA: polyunsaturated FA; n-3: omega-3 FA

\begin{tabular}{|lrrrr|}
\hline \multirow{2}{*}{ FA } & \multicolumn{2}{c}{ Muscle } & \multicolumn{2}{c|}{ Hepatopancreas } \\
& Healthy & Affected & Healthy & Affected \\
& $(\mathrm{N}=15)$ & $(\mathrm{N}=23)$ & $(\mathrm{N}=10)$ & $(\mathrm{N}=12)$ \\
\hline $14: 0$ & $1.0 \pm 0.1$ & $1.1 \pm 0.2$ & $1.8 \pm 0.7$ & $1.8 \pm 0.6$ \\
$16: 0$ & $20.5 \pm 0.9$ & $20.2 \pm 1.4$ & $15.2 \pm 1.9$ & $15.0 \pm 1.4$ \\
$16: 1(\mathrm{n}-7)$ & $4.2 \pm 0.8$ & $4.0 \pm 0.7$ & $5.7 \pm 2.0$ & $5.5 \pm 1.5$ \\
$16: 3(\mathrm{n}-4)$ & $0.6 \pm 0.2$ & $0.7 \pm 0.2$ & $0.9 \pm 0.3$ & $0.9 \pm 0.2$ \\
$17: 0$ & $1.0 \pm 0.1$ & $1.0 \pm 0.1$ & $0.7 \pm 0.2$ & $0.8 \pm 0.1$ \\
$18: 0$ & $4.1 \pm 0.7$ & $4.0 \pm 0.6$ & $3.6 \pm 0.7$ & $3.5 \pm 0.6$ \\
$18: 1(\mathrm{n}-9)$ & $9.3 \pm 0.8$ & $9.3 \pm 1.2$ & $10.0 \pm 2.1$ & $10.1 \pm 1.8$ \\
$18: 1(\mathrm{n}-7)$ & $5.0 \pm 0.5$ & $5.1 \pm 0.6$ & $5.6 \pm 0.6$ & $5.6 \pm 0.9$ \\
$18: 2(\mathrm{n}-6)$ & $1.2 \pm 0.1$ & $1.2 \pm 0.2$ & $1.2 \pm 0.3$ & $1.2 \pm 0.2$ \\
$20: 1(\mathrm{n}-11)$ & $0.3 \pm 0.1$ & $0.2 \pm 0.1$ & $0.7 \pm 0.5$ & $0.9 \pm 0.4$ \\
$20: 1(\mathrm{n}-9)$ & $0.3 \pm 0.1$ & $0.3 \pm 0.3$ & $1.0 \pm 0.4$ & $0.8 \pm 0.3$ \\
$20: 1(\mathrm{n}-7)$ & $0.3 \pm 0.1$ & $0.4 \pm 0.2$ & $1.1 \pm 0.6$ & $1.2 \pm 0.3$ \\
$20: 4(\mathrm{n}-6)$ & $3.6 \pm 0.4$ & $3.6 \pm 0.4$ & $3.8 \pm 0.7$ & $3.7 \pm 0.8$ \\
$20: 5(\mathrm{n}-3)$ & $22.6 \pm 1.0$ & $23.0 \pm 1.3$ & $21.1 \pm 3.1$ & $21.3 \pm 2.2$ \\
$22: 5(\mathrm{n}-3)$ & $1.2 \pm 0.2$ & $1.3 \pm 0.3$ & $1.6 \pm 0.7$ & $2.1 \pm 0.7$ \\
$22: 6(\mathrm{n}-3)$ & $21.6 \pm 2.0$ & $21.2 \pm 2.1$ & $18.3 \pm 4.6$ & $18.4 \pm 3.5$ \\
$\Sigma$ SFA & $28.1 \pm 1.5$ & $27.9 \pm 2.1$ & $23.6 \pm 2.8$ & $23.4 \pm 2.4$ \\
$\sum$ MUFA & $19.7 \pm 1.5$ & $19.9 \pm 1.8$ & $25.1 \pm 3.7$ & $25.2 \pm 2.9$ \\
$\Sigma$ PUFA & $52.1 \pm 1.6$ & $52.1 \pm 2.7$ & $50.9 \pm 5.7$ & $51.1 \pm 4.7$ \\
$\Sigma \mathrm{n}-3$ & $46.2 \pm 1.7$ & $46.1 \pm 2.6$ & $43.1 \pm 5.8$ & $43.5 \pm 4.5$ \\
& & & & \\
\hline
\end{tabular}

mei and the giant freshwater prawn Macrobrachium rosenbergii (Bragagnolo \& Rodriguez-Amaya 2001, PerezVelazquez et al. 2003, Martínez-Alarcón et al. 2019). Mika et al. (2014) and Turan et al. (2011) also reported similar compositions, with principal fatty acids such as 16:0, 18:1(n-9), 20:5(n-3), and 22:6(n-3) in C. crangon from the White Sea and Black Sea.

In contrast to our findings, muscle tissues of the American lobster Homarus americanus affected by shell disease revealed slightly higher ratios of 20:4(n-6) and 22:6(n-3) compared to healthy lobsters (Floreto et al. 2000). In addition, a lower HIS, as well as significantly lower lipid levels, were measured in the hepatopancreas of affected $H$. americanus. The authors concluded that lobsters affected by shell disease have either a reduced capability to store lipids, or exhibit a higher energetic requirement compared to healthy individuals. As in our study, the constitution and biochemistry of the

(PUFAs) between affected and healthy shrimp differed neither in the muscle (SFAs: $t=0.240, \mathrm{p}=$ 0.811; MUFAs: $t=-0.308, \mathrm{p}=0.760$; PUFAs: $t=0.020$, $\mathrm{p}=0.984$ ) nor in the hepatopancreas (SFAs: $t=0.221$, $\mathrm{p}=0.828$; MUFAs: $t=-0.047, \mathrm{p}=0.963$; PUFAs: $t=$ $-0.090, \mathrm{p}=0.930$ ) (Table 3).

\section{DISCUSSION}

In this study, we examined the biochemical profiles of healthy and shell-disease affected Crangon crangon to assess possible effects of the classical shell disease on the nutritional composition of this food product. We detected no differences in total protein or lipid contents, or in the fatty acid compositions, between healthy and affected brown shrimp, pointing to a similar nutritional value of both groups. The muscle tissue of all $C$. crangon was rich in PUFAs, especially in the omega-3 fatty acids EPA and DHA. These are the most common fatty acids found in seafood and have been associated with many health benefits for humans (Harper \& Jacobson 2005, Vaughan et al. 2013, Calder 2017). The amounts of these dominant fatty acids are in accordance with previous findings for C. crangon and other decapods, such as the whiteleg shrimp Litopenaeus vanna- lobsters may not be affected by large, superficial black ulcers, but rather by lesions that have already penetrated the cuticle into the soft tissue. In our study, in spite of shell disease, affected C. crangon do not use more of their energy stores when compared to healthy shrimp, pointing towards a stable physiological state in terms of biochemical composition. Hence, our results suggest that in C. crangon, classical shell disease predominantly generates superficial symptoms, as indicated by the black necrotic lesions on the cuticle. Other studies suggest that all layers of the cuticle, as well as the soft underlying tissue, of brown shrimp may be affected by shell disease (Schlotfeldt 1972, Segelken-Voigt et al. 2018).

In our study, no signs of necrotic lesions were observed on the epidermis of C. crangon specimens, thus the lesions were apparently not severe enough to penetrate the different shell layers and to impair the vitality of $C$. crangon. It has previously been stated for $C$. crangon that necrotic lesions remain superficial on the epicuticle or develop at the end of a molting cycle and that brown shrimp can diminish or even eliminate black spots via ecdysis (Smolowitz et al. 1992, Segelken-Voigt et al. 2018). Our data and literature studies suggest that the high molting frequencies in $C$. crangon minimize the progression of the disease symptoms into 
deeper layers of the cuticle, internal organs, and tissues. Brown shrimp have a fast molting rate of approximately 3 wk (Hufnagl \& Temming 2011) and a short intermolt period. Hence, these shrimp have little time to develop shell-disease-induced lesions compared to adult American lobsters that have a molting rate of approximately once per year (Hughes \& Matthiessen 1962).

Despite the fact that brown shrimp can heal itself of the black necrotic lesions by molting, we cannot exclude an effect of shell disease on biochemical and physiological processes in C. crangon. For example, an infestation with black spots can reduce the respiratory performance of affected shrimp (SegelkenVoigt et al. 2018), and, in the worst case, the bacteria may cause a sepsis, possibly leading to death (Smolowitz et al. 1992, Vogan et al. 1999, Vogan \& Rowley 2002). Consequently, we cannot exclude the possibility that the microbiological quality of shrimp as a consumer product will be affected by shell disease, while the nutritional value remains at a high level.

Shell disease can also cause significant alterations in the immune system of crustaceans, by a reduction of serum protein, via low concentrations of circulating hemocytes in the hemocoel, by destruction of blood cells through phagocytosis (Prince 1997), or by an enhancement of hemocytes in the hemolymph by increased immune activity in affected individuals (White \& Ratcliffe 1982, Vogan \& Rowley 2002). Therefore, future studies should address the immune-system responses of affected brown shrimp and examine the biochemical composition of C. crangon bearing lesions that have already penetrated the epidermis.

\section{CONCLUSIONS}

Our findings show that as long as the black ulcers are superficial, shell disease in Crangon crangon does not affect its energy stores or biochemical profiles. No significant alterations in the biochemical composition or the HSI were detected in shrimp affected by shell disease compared to healthy specimens. Total protein and lipid contents, as well as fatty acid compositions in muscle and hepatopancreas, remained similar between healthy and affected shrimp. We thus conclude that the nutritional value of superficially affected brown shrimp is maintained, including the levels of essential omega-3 fatty acids such as EPA and DHA.
Acknowledgements. Special thanks to Sabrina Dorschner for technical assistance during biochemical analyses in the laboratory. We also thank the captain and crew of RV 'Uthörn' for their support during sampling of the brown shrimp. HIFMB is a collaboration between the Alfred Wegener Institute Helmholtz-Center for Polar and Marine Research and the Carl-von-Ossietzky University Oldenburg, initially funded by the Ministry for Science and Culture of Lower Saxony and the Volkswagen Foundation through the 'Niedersächsisches Vorab' grant program (grant number ZN3285). English-language services were provided by stels-ol.de.

\section{LITERATURE CITED}

Anderson MJ (2001) A new method for non-parametric multivariate analysis of variance. Austral Ecol 26:32-46

Ayres P, Edwards E (1982) Notes on the distribution of 'black spot' shell disease in crustacean fisheries. Chem Ecol 1: 125-130

* Barris BN, Shields JD, Small HJ, Huchin-Mian JP and others (2018) Laboratory studies on the effect of temperature on epizootic shell disease in the American lobster Homarus americanus. Bull Mar Sci 94:887-902

* Beukema JJ, Dekker R (2005) Decline of recruitment success in cockles and other bivalves in the Wadden Sea: possible role of climate change, predation on postlarvae and fisheries. Mar Ecol Prog Ser 287:149-167

*Bagagnolo N, Rodriguez-Amaya D (2001) Total lipid, cholesterol, and fatty acids of farmed freshwater prawn (Macrobrachium rosenbergii) and wild marine shrimp (Penaeus brasiliensis, Penaeus schmitti, Xiphopenaeus kroyeri). J Food Compos Anal 14:359-369

* Calder PC (2017) New evidence that omega-3 fatty acids have a role in primary prevention of coronary heart disease. J Public Health Emerg 1:35

Castro K, Angell T (2000) Prevalence and progression of shell disease in American lobster, Homarus americanus, from Rhode Island waters and the offshore canyons. J Shellfish Res 19:691-700

Castro KM, Factor JR, Angell T, Landers DF Jr (2006) The conceptual approach to lobster shell disease revisited. J Crustac Biol 26:646-660

Chang ES, O'Connor JD (1983) Metabolism and transport of carbohydrates and lipids. In: Mantel LH (ed) The biology of Crustacea, Vol 5. Internal anatomy and physiological regulation. Academic Press, New York, NY, p 263-287

Chen JC, Lin MN, Ting YY, Lin JN (1995) Survival, haemolymph osmolality and tissue water of Penaeus chinensis juveniles acclimated to different salinity and temperature levels. Comp Biochem Physiol A Physiol 110: 253-258

Chistoserdov A, Smolowitz R, Mirasol R, Hsu A (2005) Culture-dependent characterization of the microbial community associated with epizootic shell disease in American lobster, Homarus americanus. J Shellfish Res 24: 741-747

Clarke KR, Gorley RN (2006) PRIMER V6: user manualtutorial. Primer-E, Plymouth

Diaz C, Sousa L, Petriella A (2010) Functional cytology of the hepatopancreas of Palaemonetes argentinus (Crustacea, Decapoda, Caridea) under osmotic stress. Braz Arch Biol Technol 53:599-608 
Dyrynda E (1998) Shell disease in the common shrimp Crangon crangon: variations within an enclosed estuarine system. Mar Biol 132:445-452

*Feinman SG, Martínez AU, Bowen JL, Tlusty MF (2017) Fine-scale transition to lower bacterial diversity and altered community composition precedes shell disease in laboratory-reared juvenile American lobster. Dis Aquat Org 124:41-54

Floreto EA, Prince DL, Brown PB, Bayer RC (2000) The biochemical profiles of shell-diseased American lobsters, Homarus americanus Milne Edwards. Aquaculture 188: 247-262

Folch J, Lees M, Sloane-Stanley G (1957) A simple method for the isolation and purification of total lipids from animal tissues. J Biol Chem 226:497-509

*arcía F, González-Baró M, Pollero R (2002) Transfer of lipids between hemolymph and hepatopancreas in the shrimp Macrobrachium borellii. Lipids 37:581-585

Getchell R (1991) Lobster shell disease survey. J Shellfish Res 10:489-490

Glenn RP, Pugh TL (2006) Epizootic shell disease in American lobster (Homarus americanus) in Massachusetts coastal waters: interactions of temperature, maturity, and intermolt duration. J Crustac Biol 26:639-645

Hagen W, Kattner G, Friedrich C (2000) The lipid compositions of high-Antarctic notothenioid fish species with different life strategies. Polar Biol 23:785-791

*Harper CR, Jacobson TA (2005) Usefulness of omega-3 fatty acids and the prevention of coronary heart disease. Am J Cardiol 96:1521-1529

Heu MS, Kim JS, Shahidi F (2003) Components and nutritional quality of shrimp processing by-products. Food Chem 82:235-242

Hoenig JM, Groner ML, Smith MW, Vogelbein WK and others (2017) Impact of disease on the survival of three commercially fished species. Ecol Appl 27:2116-2127

Hufnagl M, Temming A (2011) Growth in the brown shrimp Crangon crangon. I. Effects of food, temperature, size, gender, moulting, and cohort. Mar Ecol Prog Ser 435:141-154

Hughes JT, Matthiessen GC (1962) Observations on the biology of the American lobster, Homarus americanus. Limnol Oceanogr 7:414-421

ICES (2015) Report of the Working Group on Crangon Fisheries and Life History (WGCRAN), 18-20 May 2015, Ijmuiden, the Netherlands. ICES Document CM 2015/ SSGEPD:07

Jiménez AG, Kinsey ST (2015) Energetics and metabolic regulation. In: Chang ES, Thiel M (eds) The natural history of the Crustacea, Vol 4. Physiology. Oxford University Press, New York, NY, p 391-419

Johnson G (1980) Energy migration and transfer in molecularly doped polymers. Macromolecules 13:145-152

Kattner G, Fricke HS (1986) Simple gas-liquid chromatographic method for the simultaneous determination of fatty acids and alcohols in wax esters of marine organisms. J Chromatogr A 361:263-268

Kattner G, Wehrtmann I, Merck T (1994) Interannual variations of lipids and fatty acids during larval development of Crangon spp. in the German Bight, North Sea. Comp Biochem Physiol B Comp Biochem 107:103-110

Kraemer P, Gerlach G, Brinkhoff T (2020) Diversity and flexibility of the bacterial communities on Cancer pagurus at different temperatures. J Sea Res 156:101827

Kruskal JB, Wish M (1978) Multidimensional scaling. Sage, Beverly Hills, CA
Kafferty KD, Harvell CD, Conrad JM, Friedman CS and others (2015) Infectious diseases affect marine fisheries and aquaculture economics. Annu Rev Mar Sci 7: 471-496

Laufer H, Demir N, Biggers WJ (2005) Response of the American lobster to the stress of shell disease. J Shellfish Res 24:757-760

Laufer H, Chen M, Johnson M, Demir N, Bobbitt JM (2012) The effect of alkylphenols on lobster shell hardening. J Shellfish Res 31:555-562

Lee RF, Hagen W, Kattner G (2006) Lipid storage in marine zooplankton. Mar Ecol Prog Ser 307:273-306

Kowry OH, Rosebrough NJ, Farr AL, Randall RJ (1951) Protein measurement with the Folin phenol reagent. J Biol Chem 193:265-275

Martínez-Alarcón D, Saborowski R, Melis E, Hagen W (2019) Seasonal lipid dynamics of the shrimps Crangon crangon and Pandalus montagui in the German Bight (North Sea). Mar Ecol Prog Ser 625:41-52

Meres NJ, Ajuzie CC, Sikaroodi M, Vemulapalli M, Shields JD, Gillevet PM (2012) Dysbiosis in epizootic shell disease of the American lobster (Homarus americanus). J Shellfish Res 31:463-472

Mika A, Gołębiowski M, Skorkowski E, Stepnowski P (2014) Lipids of adult brown shrimp, Crangon crangon: seasonal variations in fatty acids class composition. J Mar Biol Assoc UK 94:993-1000

*Perez-Velazquez M, González-Félix ML, Lawrence $\mathrm{AL}$, Gatlin DM (2003) Changes in lipid class and fatty acid composition of adult male Litopenaeus vannamei (Boone) in response to culture temperature and food deprivation. Aquacult Res 34:1205-1213

Prince DL (1997) Studies on the etiology and pathogenesis of shell disease in the American lobster, (Homarus americanus). $\mathrm{PhD}$ thesis, University of Maine, Orono, $\mathrm{ME}$

Revill AS, Holst R (2004) Reducing discards of North Sea brown shrimp (C. crangon) by trawl modification. Fish Res 68:113-122

Rosen B (1967) Shell disease of the blue crab, Callinectes sapidus. J Invertebr Pathol 9:348-353

* Sacristán HJ, Rodríguez YE, De los Angeles Pereira N, Greco LSL, Lovrich GA, Gimenez AVF (2017) Energy reserves mobilization: strategies of three decapod species. PLOS ONE 12:e0184060

Schlotfeldt H (1972) Jahreszeitliche Abhängigkeit der 'Schwarzfleckenkrankheit' bei der Garnele, Crangon crangon (L). Ber Dtschn Wiss Komm Meeresforsch 22: 397-399

Segelken-Voigt A, Miller MG, Gerlach G (2018) Shell disease in Crangon crangon (Linnaeus, 1758): links between elevated temperature on the progression of black spots and the life history characteristics of the host. J Exp Mar Biol Ecol 500:105-111

Shields JD (2013) Complex etiologies of emerging diseases in lobsters (Homarus americanus) from Long Island Sound. Can J Fish Aquat Sci 70:1576-1587

Smolowitz RM, Bullis RA, Abt DA (1992) Pathologic cuticular changes of winter impoundment shell disease preceding and during intermolt in the American lobster, Homarus americanus. Biol Bull (Woods Hole) 183: 99-112

* Smolowitz R, Chistoserdov AY, Hsu A (2005) A description of the pathology of epizootic shell disease in the American lobster, Homarus americanus, H Milne Edwards 1837. J Shellfish Res 24:749-756 
Tarrant AM, Franks DG, Verslycke T (2012) Gene expression in American lobster (Homarus americanus) with epizootic shell disease. J Shellfish Res 31:505-513

Tlusty MF, Smolowitz RM, Halvorson HO, DeVito SE (2007) Host susceptibility hypothesis for shell disease in American lobsters. J Aquat Anim Health 19:215-225

Turan H, Kaya Y, Erdem ME (2011) Proximate composition, cholesterol, and fatty acid content of brown shrimp (Crangon crangon L 1758) from Sinop region, Black Sea. J Aquat Food Prod Technol 20:100-107

Vaughan VC, Hassing MR, Lewandowski PA (2013) Marine polyunsaturated fatty acids and cancer therapy. $\mathrm{Br} \mathrm{J}$ Cancer 108:486-492

Verslycke T, Vercauteren J, Devos C, Moens L, Sandra P, Janssen CR (2003) Cellular energy allocation in the estuarine mysid shrimp Neomysis integer (Crustacea: Mysidacea) following tributyltin exposure. J Exp Mar Biol Ecol 288:167-179

Vogan CL, Rowley AF (2002) Effects of shell disease syn-

Editorial responsibility: Jeffrey Shields, Gloucester Point, Virginia; USA drome on the haemocytes and humoral defences of the edible crab, Cancer pagurus. Aquaculture 205: 237-252

*Vogan CL, Llewellyn PJ, Rowley AF (1999) Epidemiology and dynamics of shell disease in the edible crab Cancer pagurus: a preliminary study of Langland Bay, Swansea, UK. Dis Aquat Org 35:81-87

* Vogan CL, Costa-Ramos C, Rowley AF (2001) A histological study of shell disease syndrome in the edible crab Cancer pagurus. Dis Aquat Org 47:209-217

*Wahle RA, Gibson M, Fogarty M (2009) Distinguishing disease impacts from larval supply effects in a lobster fishery collapse. Mar Ecol Prog Ser 376:185-192

White K, Ratcliffe N (1982) The segregation and elimination of radio and fluorescent-belled marine bacteria from the haemolymph of the shore crab, Carcinus maenas. J Mar Biol Assoc UK 62:819-833

Young JS, Pearce JB (1975) Shell disease in crabs and lobsters from New York Bight. Mar Pollut Bull 6:101-105

Submitted: June 20, 2020; Accepted: July 17, 2020

Proofs received from author(s): September 20, 2020 